\title{
Western Exploitations and the Nexus of African Underdevelopment
}

\author{
Jibrin Ubale Yahaya, Ph.D \\ Department of Political Science, National Open University of Nigeria (NOUN)
}

\begin{abstract}
This paper examines Walter Rodney's argument of How Europe Underdeveloped Africa and its justification years after political independence. The paper has adapted Dependency Theory. The paper has reveals that widening gap between Developed and Underdeveloped States is as a result of both external and internal factors especially the colonial integration of African economies in the World Capitalist System and its exploitative institutions and programmes and internal factors of both systemic and institutional corruption, political instability, colonial mentality of consumption and other factors are responsible for underdevelopment of Africa with attendant effects of poverty, inequality, unemployment, disease and infrastructural decay etc. on basis of conclusion. The paper recommended that visionary and purposeful leadership that surrounds itself with experts will initiate and sustain revolutionary development in Africa. Also proper planning and continuity in developmental policies and programmes and united front against corruption be strictly adhered to for the continent to develop.
\end{abstract}

Keywords: Development, Underdevelopment, Exploitations and Good Governance.

DOI: $10.7176 / \mathrm{JAAS} / 64-06$

Publication date:May $31^{\text {st }} 2020$

\section{Introduction}

The widening gap between the developed and developing countries has become a central problem of our time. Current world development indicators even show worsening indices of human development in the global growth especially sub-Saharan Africa. And with the gap comes issues of migration, environmental pressures, conflict, instability and other problems rooted in global poverty and inequality. Walter Rodney in his introductory chapters of "How Europe Underdeveloped Africa pointed out and I quote:

"The question as to whom and what is responsible for Africa Underdevelopment can be answered at two levels. Firstly, the answer is that the operation of the imperialist system been major responsibility for African economic retardation by draining Africa Wealth and by making it impossible to develop more rapidly the resources of the continent. Secondly, one has to deal with those who manipulated the system and those who are either agents or unwitting accomplices of the said system" Rodney, W. (1972: xii)

\section{Statement of Problem}

The literature on development and underdevelopment is extensive and varied even as the concept is perceived in various dimensions. Development is a multidimensional process involving major changes in the social structures, popular attitudes, national institutions, as well as the acceleration of economic growth, the reduction of inequality and the eradication of poverty. Development in its essence must represent the whole gamut of charge by which an entire social system moves away from a condition of life widely perceived as unsatisfactory towards a situation or condition of life regarded as materially and spiritually better (Tadaro and Smith, 2004).

Todaro and Smith (2004) conclusively posited that development is both a physical reality and a state of mind in which society has through some combination of social, economic and institutional process, secure the means for obtaining a better life; development in all society must have at least the following three objectives:

- To increase the availability and widen the distribution of basic life sustaining goods such as food, shelter, health and protection.

- To raise levels of living, including in addition to higher incomes, the provision of more jobs, better education, and greater attention to cultural and human value, all of which will serve to enhance material well being and generate greater individual and national self esteem.

- To expand the strange of economic and social choices available to individuals and nations by freeing them from servitude and dependence not only in relation to other people and nation state but also to the forces of ignorance and human misery.

An important deduction from the above conceptualization and estimation of development is that, development implies the capacity to secure and sustain a better life for human kind in society. The striving to elevate human life and comfort from a given level considered unsatisfactory to a better, perhaps more comfortable level. 


\section{Research Questions}

The paper has the following questions to ask:

i. What are the causes of African economic exploitations?

ii. What is nature of African economic exploitation?

iii. Is there any ways for African countries to recover from past economic exploitation?

\section{Research Objective}

The paper has the general objective of investigating the problem of African economic exploitation with the following specific objectives:

i. To examine the causes of African economic exploitations

ii. To find out the nature of African economic exploitation

iii. To investigate the ways in which African countries would recover from past economic exploitation

\section{Research Methodology}

The researcher has the uses secondary source of data through using various literatures on the issues of African economic exploitation and finding ways to suggest how African countries would recover from the past economic underdevelopment as a result of superpower countries economic exploitations.

\section{Conceptual Clarifications Development}

Dudley Seers (1969) posited that the questions to ask about a country development are that what is happening to poverty? What is happening to unemployment? What is happening to inequality?

If the three of these have declined from high levels, then beyond doubt, these have been a period of development for the country concerned.

Rodney (1972) views development in human society as a many sided process. At the level of individual, it implies increased skills and capacity, greater freedom, creativity, self discipline, responsibility and material well being. At the level of society, development means increasing capacity to regulate both internal and external relationship.

Development cannot be seen purely as economic affairs, but rather as an overall social process which is dependent upon the outcome of man's efforts to deals with the natural environment.

Development is about people - the mental state of the people, the economic, social and institutional activities and arrangement, the people are capable of putting in place and enhance a better life in a given society.

\section{Underdevelopment}

Dudley Seer (1969), underdevelopment is the worsening experience of the indices of poverty, unemployment, inequality or any two thereof in a given country.

Todaro and Smith (2004) argue that the phenomenon of underdevelopment is not merely a question of economics or one of qualitative measurement of income, employment and inequality. Underdevelopment is a state of the mind as much as a state of national poverty.

Keenleyside cited by Abraham, postulated that, underdevelopment is characterized by, (1) the incidence of poverty, ignorance or disease (2) Mal distribution of the national income, (3) administrative incompetence and (4) social disorganizations. Citing also Kuznete by Abraham N.T (2010), underdevelopment may mean either (1) failure to utilize fully the productive potential warranted by the existing state of technical knowledge, a failure resulting from the resistance of social institutions (2) backwardness in economic performance compared with the few economically leading countries of the period (3) economic poverty in the sense of failure to ensure adequate subsistence and material comfort to most of the country's population.

Rodney (1972), underdevelopment is not absence of development, because every people have developed in one way or another and to a greater or lesser extent. Underdevelopment makes sense only as a means of comparing levels of development. It is very much tied to the fact that human social development has been un even from the strict economic view point, some human groups have advance further by producing more and becoming more and becoming more wealthier.

He stressed further that, at all times, therefore, one of the idea behind underdevelopment is a comparative one.

Goulet (1971) as cited by Abraham has this to say on underdevelopment; underdevelopment is shocking; the squalor, disease, unnecessary deaths, and hopelessness of it all. To Goulet, the most emphatic observer can speak objectively about underdevelopment only after undergoing, personally or vicariously, the shock of underdevelopment.

Abraham N.T (2005) identified the characteristic of underdevelopment to include:

- Incidence of poverty/low levels of living 
- Dependency (external influence, reliance and manipulations)

- Alien state/government

- Dual political culture and conflict of allegiance

- Production of primary commodities

- Low productivity

- Import oriented economy

- Mono-cultural economy

- Corruption/Nepotism

- Fatal political context/crises

- Low level of technology/research

- Dislocation of indigenous cultural heritage and value.

- Dependency on primary export

- Susceptibility to westernization/cultural shock

- Susceptibility of exploitation by external forces and multinationals.

\section{Political Independence}

Political independence refers to governments that are sovereign, that is, the right to exercise freely the full range of power a state possesses under international law. It means countries legally are able to make their own decision about their domestic and foreign policies without external interference.

Saleh, D. (2012) asserts that political independence of most of African States created a relatively stable order in the continent than before and the above led to reshaping of the political map of Africa.

The gaining of political independence by majority of Africa States in 1960s led to an increase in the desire for African Unity and regional groupings. Most African States saw the need to establish regional bodies facilitate regional integration and hence promote economic development.

Ake C (1996), is of the view that, although political independence of African States brought some changes to the composition of state managers, the character of the state remained much as it was in the colonial era. It continued to be totalistic in scope, constituting a statist economy. Ake further stressed that, with few exceptions, the gaining of political independence was not a matter of nationalistic marshaling forces to defeat colonial regimes; more often than not, it was a matter of the colonizers accepting the in inevitable and orchestrating a handover of government to their chosen African successors, successors who could be trusted to share their values and be attentive to their interest.

To Ake, by the time political independence was achieved in the early 1960s, the centrifugal tendencies had grown strong enough in many countries of Africa to threaten not only the transition to independence but, more important, the political viability of new government, and the a political environment at independence was profoundly hostile to development.

Fanon, F. (1967) collaborates Ake and posited further that "today national independence and the growth of national feelings in Underdeveloped regions take a total new aspect. In these regions, with the exception of certain spectacular advances, the different countries show the same absence of infrastructure, the masses of the people struggle against the same poverty and with their shrunken bellies outline what has been called geography of hunger" (Fanon 1966:78)

\section{Economic Independence}

Economic Independence is the control of the wealth of a nation by the majority of its citizen. This means local ownership of resources and the means of production for the utilization of natural wealth.

Rodney (1972) asserted that, throughout the period that Africa has participated in the capitalist economy, two factors have brought about underdevelopment. In the first place, the wealth created by African labour and from African resources was grabbed by the capitalist countries of Europe, and secondly restrictions were placed on African capacity to make a maximum use of its economic potential which is what development is all about.

He pointed out further that, African economies were integrated into the very structure of the developed capitalist economies and were integrated in a manner that is unfavourable to Africa and ensures that Africa is dependent on the big capitalist countries. Indeed, structural dependence is one of the characteristic of underdevelopment.

Rodney stressed further that, the question as to who and what is responsible for African underdevelopment can be answered at two levels; firstly, the answer is that the operation of the imperialist system bears major responsibility for African economic retardation by draining African wealth and by making it impossible to develop more rapidly the resources of the continent.

Secondly, one has to deal with those who manipulate the system and those who are either agents or unwitting accomplices of the said system. 


\section{Theoretical Framework}

The concept of development and underdevelopment and the issues associated with can be explained using a plethora of theoretical analysis, depending on the dimension of the scholar's line of argument.

This work will however adopt "Dependency Theory" in explaining the level of underdevelopment of African states.

The theory arose in the 50s as a reaction to some earlier theories of development which held that, all societies progress through similar stages, that today's underdevelopment areas are thus in a similar situation to that of today's developed areas at sometimes in the past, and that therefore the task in helping the underdeveloped areas out of poverty is to accelerate them along this supposed common path of development, by various means such as, investment, technology transfers, and closer integration into the world market.

The theory is predicted on the notion that resources flow from the "Periphery" of poor and underdeveloped States of the "Core" of Wealthy States, enriching the latter at the expense of the former. It is the central contention of the Dependency school that, Poor States are impoverished and rich ones enriched by the way poor states were integrated into the world system'.

The prominent scholars of this School, include: Frank, Theotonio Dos Santos, Samir Amin, Rodney etc. The premises of Dependency Theory are that;

1. Poor nations provide natural resources, cheap labour, a destination for obsolete technology and market to the wealthy nations, without which the latter could not have the standard of living they enjoy.

2. Wealthy nations actively perpetuate a state of dependence by various means. This influence may be multifaceted, involving economics, media control, politics, banking and finance, education, culture, sport and all aspect of human resources development (including recruitment and training of workers).

3. Wealthy nations actively counter attempts by dependent nations to resist their influences by means of economic sanctions and/or the use of military force. The argument of these scholars explains the situation of African States today.

\section{How Africa Developed Before the Coming of the Europeans}

Casely - Hayfor, J.E. (1922) as cited by Rodney; before even the British came into relations with our people, we were developed people, having our own institutions, having our ideas of government.

Rodney (1972) stressed that, African achievements of the Pre-European period stand as contributions to man's heritage of beautiful creations.

"The art of Egypt, the Sudan and Ethiopia was known to the rest of the World at the early date... The verdict of art historians on the Ife and Benin bronzes is well known. Since they date from the $14^{\text {th }}$ and $15^{\text {th }}$ centuries, they are very relevant to any discussion of African development in the epoch before the contact with Europe". (Rodney 1972:38)

He posited further that, the features of traditional African religion helped to set Africa cultures apart from those in other continents. On agriculture, Rodney stressed that, in the centuries before the contact with Europeans, the overwhelming dominant activity in Africa was agriculture. In all the settled agricultural communities, people observed the peculiarities of their own environment and tried to find techniques for dealing with it in a rational manner; advance methods were used in some area such as terracing, crop rotation, green manuring and mixed farming and regulated swamp farming. The introduction of iron tools notably the axe and the hoe; it was on the basis of the iron tools that new skills were elaborated in agriculture as well as in other spheres of economic activities.

In manufacturing sector, Rodney went ahead to stress that, Africa manufacturers made a breakthrough, and it was a way of judging economic development in Africa, five centuries ago and the quality of the product of Africa. The red leather which was termed "Moroccan Leather" the tanned and dyed leather works by Hausa and Mandinga Specialist in Northern Nigeria and Mali will attest to this.

Rodney pointed clearly that, in the area of trade, Africa was a continents of numerable routes, some extended for huge distances, like the route across the Sahara or the routes connected with Katanga Copper. Various communities where producing surplus of given commodities which could be exchanged for items which they lacked, the extension of trade saw "Barter" giving way to some money exchange.

The social patterns and political units were also developed predominantly principle of social relation was that of family and kingship associated with communalism. Some cultures had relatively advanced material and nonmaterial cultures. For instance, Ibo in Nigeria and Kikuyu of Kenya both has sophisticated system of political rule based on clans, religious oracles and secret societies.

Rodney concluded by pointing out some concrete examples of African development such as; Egypt which flourished in science, education, Ethiopia which the wealth rested on architectural and agricultural achievements, production of garments and Jewellery, the brass work in Nambia, the striking achievement of the Muslim Maghreb in area of naval, military, commercial and cultural sphere. 
As one of index to the standard of social life, Rodney pointed out that, public baths were common in the cities of Maghreb at a time when in the Oxford the doctrine was still being propounded that, the washing of the whole body was a dangerous act.

Considering the above concrete example therefore, it has been proven beyond doubt that Africa developed before the coming of the Europeans.

\section{Europe and the Root of African Underdevelopment}

The root cause of African underdevelopment is seen in the contact between African and the European; this was seen in the European slave trade, technological stagnation and distortion of African economies in the pre-colonial epoch, and the coming of colonialism and imperialism.

Rodney has this to say on the slave trade:

"Many things remain uncertain about the slave trade and its consequences for Africa, but the general picture of destructiveness is clear, and the destructiveness can be shown to be the logical consequence of the manner of recruitment of captives in African. One of the uncertainties concerns the basic question of how many African were imported this has long been object of speculation, which estimates ranging from a few millions to over one hundred millions" (Rodney 1972:109)

The massive loss of African labour force was made more critical because, it was composed of able - bodied, young men and women preferably between the ages of $15-35$ years (productive age).

African economic activities were affected both directly and in directly by population loss, and the achievement of economic development was distorted.

Rodney (1972), in the centuries before colonial rule, Europe increased its economic capacity by leaps and bounds, while Africa appeared to have been almost static. Africa in the late 19 centuries could still be described as part of communal and feudal, while Western Europe had moved completely from feudal to capitalism.

The growing technological and economic gap between Western Europe and Africa was part of the trend within capitalism to concentrate or polarize wealth and poverty at two opposite extremes.

European monopoly firms operated by constantly fighting to gain control over raw materials, markets, and means of communications, they also fought to be the first to invest in new profitable undertaking related to their line of business whether it be inside or outside their countries.

Indeed after the scope for expansion became limited inside of their national economies, their main attention was turned to those countries whose economies were less developed and who would therefore offer little or no opposition to the penetration of foreign capitalism, and this penetration on world-wide scale in 19 century is termed imperialism and it is essentially an economic phenomenon.

Collaborating Rodney, Ake (1979) posited that, colonization that occurred in Africa in the last three decade of nineteenth century, a lot of factors attributed to that, but economic factors played the central role.

\section{Africa and Underdevelopment after Political Independence}

Ake C. (1996), although political independence brought some changes to the composition of State managers, the character of the State remained much as in the colonial era. The political environment at independence was profoundly hostile to development, principally because of the incorporation of Africa economies into the world capitalist system and the structural constraints associated with it did not entirely preclude the option of self-reliant development. In the final analysis, development was a politically driven decision hinging on consideration of political survival, considerations that impelled African leaders to marginalize development and even their roles in its pursuit. It is indicative of their limited commitment to development that with few exceptions, African countries came to independence with hardly any discernible vision of development and no agenda for its realization. Most of the newly independent countries relied heavily on expatriates for their development plan, which were usually collections of polices targets and programmes that took for granted the validity of the inherited economic structure. Moreover, the gaining of political independence was not a matter of nationalists marshalling forces to defeat colonial regimes. But the handover of government to African leaders was to those that will protect their interest. The above factors established a background of what, i may consider as both external and internal reason for Africa underdevelopment after political independence.

\section{External Factors/Reasons}

\section{Colonial Exploitative Financial Institutions (Breton Woods Institutions)}

They were setup at a meeting of 43 countries in Bretton Woods, New Hampshire, USA in July 1944 with the aim of rebuilding the shattered post war economy and promote international economic cooperation. The activities of the Bretton Woods Institutions i.e. World Bank and International Monetary Fund (IMF) are factors affecting African development. Some of the loans given to African countries from these institutions are not meant for development due to the conditions attached to it. These institutions requires the recipient to pay for consultancy, 
which often takes half of the loan, the consultant being the expatriates, the purchase of the material for the execution of the project, usually also from the West, notably the major financial contributors. This is part of the dependent nature which still exists in African continent causing underdevelopment in the continent (Ake 1996).

\section{Private Foreign Investment and Multinationals}

Foreign investment involves capital flows from one country to another, granting extensive ownership stakes in domestic companies and assets. It denotes that foreigners have an active role in management as a part of their investment.

\section{Multinational Corporations}

A Multinational Corporation is a company, firm or enterprise with its headquarters in a developed country such as United States of America, Germany, Britain etc, and also operates in other countries, both developed and developing. They are engage in a wide range of activities from mining, oil extraction and refining, manufacturing for home production and exports.

Abraham NT (2010) citing Sanjaya Lai and Streeten consider Multinational Corporations in three perspectives; economic organizational and motivational view points. Multinational Corporation overwhelmingly dominates not only global investment but also international production, trade, finance and technology.

Rodney and Ake and most of the third world scholars have come to regard Multinational Corporations as agent of exploitation in Less Developed Countries.

\section{Foreign Aids}

Foreign Aids also known as International Aids is economic, strategic, technical or financial assistance given by a wealthier country or group of countries to another usually on international or intergovernmental levels. Foreign Aids programs of developed nations have had strong economic rationale, private investment and expansion of trade.

Foreign Aids promote growth and structural transformation in many Less Developed Countries. Critic however argued that, Foreign Aids retard growth by substituting for, rather than supplementing domestic savings and investment and by exacerbating Less Developed Countries balance of payment deficit as a result of rising debt repayment, obligations and the linking of Aids to donor country's export.

Foreign Aids has failed to improve the income earning capacity of Less Developed Countries and are now saddled with large external public debts (Hassan, A.S (1999).

\section{Foreign Debt Crisis}

The problem of external or foreign debts of third world countries (Africa inclusive) is serious one because, they depend heavily on inflows of capital from abroad or developed countries to finance their development needs. The rate of domestic savings in Africa is low. In order to accelerate the rate of economic development, they borrow to import capital goods, components, technical know-how etc. These lead to huge current account balance of payment deficits.

Abraham, N.T (2011) pointed out that, the total debt burden of developing countries (Africa inclusive) increased from $\$ 1,460$ billion in 1990 to $\$ 2,350$ billion in 2010 .

Nigeria's foreign debts as of second quarter of 2016 stood at \$11,261.89 billion, recently, Mr Nwankwo (The Director General Debt Management Office Abuja) informed the Senate of the Federal Republic of Nigeria that, Nigeria's foreign debts stood at \$56billion as at first quarters of 2017.

\section{Internal Factors/Reasons}

Corruption: Both institutional and systemic corruption in Parastatals and Agencies of government even in Private sector are alarming, and this impedes on development of Africa. Recently, corruption in Nigeria National Petroleum Corporation where billions of Naira and Dollars are stolen on daily basis, ranging from N6.4 trillion, $\$ 16$ billion in both August $4^{\text {th }} 2015$ and March $15^{\text {th }} 2016$, and the recent discovery of $\$ 9.8$ million Dollars in the house of the former General Managing Director of NNPC will attest to this fact. More disturbing also there is no proper account of crude oil production and export in the country, the official output is 2.2 million barrels per day the exact amount of crude oil production in Nigeria is not known. The Authority Newspaper-Abuja on one of its captions of $21^{\text {st }}$ February, 2017 had this; "Nigeria has no record of oil export under Buhari". Also Hon. Ehiozuwa Agbonayinma (Adhoc Committee Chairman in the House of Representative investigating Ministry of Transport revealed recently that 19 million tons of crude oil taken to China at the estimated cost of $\$ 7$ billion was not accounted for. This is one of the factors that has affected the development pattern of Africa leading to underdevelopment, due to selfish and corrupt practices of African leaders who only think of enriching themselves to the detriment of the masses. 


\section{Political Instability}

Also African continent has witnessed series of political instability ranging from military takeover; to civil war etc. the political disorders have widely affected the development process of Africa (Ake 1996).

\section{Colonial Mentality}

Colonial mentality of consumption rather than producing which i may termed "cargo economy", has impacted negatively on development of African States, as most of the African State are rather involved in consumption of imported goods which cost billions of dollars rather than production.,

\section{Lack of Continuity in Developmental Policies and Programs of Government}

Most government developmental programmes and project are either abandoned or discontinued and new project that suits the leaders intention are embarked upon possibly for selfish reasons living the African States in a dilapidated development situation.

\section{Critique}

The principal criticism of this work is that in spite of encounter with the colonial powers that retarded African development, internal factors such as endemic corruption both systemic and institutional, political instability and other internal factors bordering on leadership and followership has impacted negatively in the development of most African countries.

Relatively, revolutionary campaigns of industrial nationalization and sustained economic developmental policies of African States have been neglected as most development policies and programmes of leaders are either abandoned or discontinued.

\section{Conclusion/Recommendations}

In conclusion, with the present state of underdevelopment in African States occasioned as a result of both external and internal factors, only visionary/purposeful leadership will initiate and sustain industrial revolution and economic growth in the continent. African leaders should surround themselves with people that have the capacity; expertise could propel the needed development in infrastructure, food security, energy etc.

Also proper planning, continuity in economic and development policies and programs, this will take in consideration economic policies and programmes that will eliminate or alleviate poverty, inequality and unemployment by various African governments. These economic policies should be aggressively pursued especially the one that will create conducive business environment, policies that allow business growth, and create a quick environment that will allow business to set in and investments in companies and protection of such investment.

Finally, uniting against corruption by all will pave way for development. Both institutional/systemic measure should be initiated to prevent people from involving in corrupt practices, and capital punishment be proscribed for those involved in corruption to serve as a deterrent to others.

\section{References}

Abraham, N.T. (2010): The Praxis of Development and Underdevelopment. Benin-City: Ethopie Publishing Corporation.

Abraham, N.T (2011): Dialectics of Underdevelopment in Africa: A Post Dependency Frame-Work. Benin-City: Ethiope Publishing Corporation.

Ake, C. (1979): Social Science as Imperialism: The Theory of Political Development, Ibadan: University Press.

Ake, C. (1981): Political Economy of Africa. Harlow: Longman Group.

Ake, C. (1996): Democracy and Development in Africa. Ibadan: Spectrum Books Limited.

Dudley, B.J. (1969): Instability and Political Order. Ibadan: University Press.

Fanon, F. (1967): The Wretched of the Earth. England: Penguin Books.

Hassan, AS. (1999): Issues in Contemporary Political Economy of Nigerian. Ilorin: Saky and Associates.

Rodney, W. (1972): How Europe Underdeveloped Africa. London: Bogle-Louverture.

Saleh, D. (2012): Politics and Government in Africa. Ibadan: Daily Graphic Nigeria Limited.

Todaro, M.P and Smith, S.C (2004): Economic Development. Delhi: Pearson Education, PTE Limited.

Channels Television Programme: Sunrise Daily on the $13^{\text {th }}$ February, 2017 with Hon. EhiozuwaAgbonyinwa (Adhoc Committee Chairman Investigating Ministry of Transport on Crude Oil Export).

The Authority Newspaper (2017) “No Record of Crude Oil Export Under Buhari”. 21 ${ }^{\text {st }}$ February, 20017 